\title{
OPTIMISASI MANAJEMEN ASET TETAP DAERAH DALAM MEWUJUDKAN GOOD GOVERNANCE DI PEMERINTAH PROVINSI DKI JAKARTA
}

\author{
Optimization of Fix Asset Management in Achieving Good Governance at The Province \\ of DKI Jakarta
}

\author{
Ika Aprilia', Yusman Syaukat ${ }^{2}$, A Faroby Falatehan ${ }^{2}$
}

1 Staff Auditor di Badan Pengawasan Keuangan dan Pembangunan (BPKP). E-mail : ikapriliaku@gmail.com 2 Staff Pengajar Departemen Ekonomi Sumberdaya dan Lingkungan. Fakultas Ekonomi dan Manajemen. IPB. E-mail : ysyaukat@gmail.com, affalatehan@gmail.com

\begin{abstract}
Local autonomy means that local governments are given freedom of action to manage and develop their own regions according to theireach condition, characters and potency. The core of local autonomy is democratization and empowerment. It is expected that the emerging democratization brings good governance into reality including good governance, both on the management of local finance and local assets. Assets or the active is one of components in the Local Government Financial Report, in which the greatest sub component is fixed assets. Therefore, good governance on fixed assets will support the efforts that have been made by the Province of DKI Jakarta to realize the good governance. Management of assets or items own by local authorities, according to Permendagri Nomor 19 tahun 2016, consists of several stages that can be classified into four managerial functions, which are planning, organizing, mobilizing or executing and controlling and monitoring. This study utilized primary and secondary data using an analysis method of gap analysis and qualitative description. Results of the study indicated that there was still a "partial gap" for each managerial function in asset management. All managerial functions had been executed moderately well in the asset management; however, the functions should be optimized further to be consistent with the prevailing laws. Based on the gap analysis, the causes of the weaknesses of asset management and the strategy move to overcome the weaknesses in the management of the most needed assets currently in the Province of DKI Jakarta.
\end{abstract}

Key Words: Managerial Function, Gap Analysis and Optimizing Asset Management Strategy

\begin{abstract}
ABSTRAK
Otonomi daerah bermakna bahwa pemerintah daerah diberikan keleluasaan untuk mengelola dan mengembangkan daerahnya sesuai kondisi, karakter dan potensinya masing-masing. Inti dari otonomi daerah adalah demokratisasi dan pemberdayaan. Demokratisasi yang ingin dimunculkan adalah mewujudkan good governance, termasuk di dalamnya tata kelola yang baik atas pengelolaan keuangan daerah dan aset daerah. Aset atau aktiva merupakan salah satu komponen dalam Laporan Keuangan Pemerintah Daerah, dengan sub komponen terbesarnya adalah aset tetap. Oleh karena itu, dengan pengelolaan aset tetap yang baik, akan mendukung upaya pemerintah Provinsi DKI Jakarta mewujudkan good governance. Pengelolaan aset atau barang milik daerah menurut Peraturan Menteri Dalam Negeri Nomor 19 Tahun 2016 terdiri dari beberapa tahapan, yang dapat diklasifikasikan secara fungsi manajerial ke dalam 4 fungsi yaitu perencanaan, pengorganisasian, penggerakan atau pelaksanaan serta pengendalian dan pengawasan. Penelitian ini menggunakan data primer dan sekunder, dengan metode analisis adalah gap analisis dan deskripsi kualitatif. Hasil penelitian menunjukkan hasil masih ada "partial gap" untuk setiap fungsi manajerial pengelolaan aset. Semua fungsi manajerial telah dijalankan dengan cukup baik dalam pengelolaan aset, namun masih perlu dioptimalkan lebih lanjut agar sesuai dengan ketentuan yang berlaku. Berdasarkan analisis gap diperoleh penyebab kelemahan pengelolaan aset sekaligus langkah strategi untuk mengatasi kelemahan dalam pengelolaan aset yang paling dibutuhkan saat ini di Pemprov DKI Jakarta.
\end{abstract}

Kata Kunci: Fungsi Manajerial, Gap Analisis, Dan Strategi Optimalisasi Manajemen Asset 


\section{PENDAHULUAN}

Gerakan reformasi pada tahun 1998 salah satunya berdampak pada lahirnya Undang-undang Nomor 22 Tahun 1999 tentang Pemerintah Daerah yang diharapkan dapat mengakomodir perubahan paradigm pemerintahan dari sentralistis menjadi desentralistis, mengedepankan prinsip-prinsip demokrasi, peran serta masyarakat, pemerataan dan keadilan, memperhatikan perbedaan potensi dan keanekaragaman, serta dapat mencegah disintegrasi bangsa. Pada tahun 2004 pemerintah menerbitkan Undang-undang Nomor 32 tahun 2004 sebagai landasan hukum pemerintahan daerah. Otonomi daerah dipahami sebagai kewenangan daerah otonom untuk mengatur dan mengurus kepentingan masyarakat setempat menurut prakarsa sendiri berdasarkan aspirasi masyarakat sesuai dengan peraturan perundang-undangan. Ada kecenderungan beberapa pandangan skeptis masyarakat terhadap pengelolaan pemerintah daerah. Masyarakat masih menangkap bahwa pengelolaan daerah masih belum dilakukan secara akuntabel dan bad governance. Transparansi dan akuntabilitas publik menjadi perhatian utama oleh masyarakat terhadap cara pengelolaan yang dilakukan oleh pemerintah daerah. Dan konsep good governance hadir untuk menampilkan susunan organisasi pemerintahan yang sederhana, agenda kebijakan yang tepat, pembagian tugas kelembagaan yang jelas, kewenangan yang seimbang, personel yang profesional, prosedur pelayanan publik yang efisien, kelembagaan pengawasan yang mantap dan sistem pertanggungjawaban yang tegas. Semangat dalam menciptakan tata kelola yang baik sejalan dengan diterbitkannya Undang-Undang Nomor 17 Tahun 2003 tentang keuangan negara, pemerintah pusat dan daerah telah berkomitmen kuat untuk membangun keuangan negara/daerah yang sesuai dengan prinsip-prinsip tata kelola pemerintahan yang baik (good governance) (Itjen DepAg, 2007). Penerapan prinsip good governance diantaranya dilakukan melalui pengelolaan keuangan dan aset yang akuntabel. Untuk pemerintah daerah, sejalan dengan otonomi daerah dan desentralisasi, bahwa pelaksanaan desentralisasi pengelolaan keuanga dari pemerintah pusat ke pemerintah daerah dan dari pemerintah daerah ke satuang kerja perangkat daerah (SKPD), tetapi juga desentralisasi pengelolaan aset daerah hingga ke level satuan kerja. Oleh karena itu menjadi sangat bagi pemerintah daerah agar aset-aset yang ada dapat dikelola secara optimal (Hidayat 2012). Selain itu manajemen aset atau pengelolaan aset menjadi sesuatu yang penting dari keseluruhan komponen pengelolaan pemerintah daerah karena aset memiliki peran strategis di dalam sebuah organisasi. Aset daerah merupakan sumber daya penting bagi pemerintah daerah sebagai penopang utama pendapatan asli daerah serta merupakan komponen yang dominan dari total aset yang dimiliki oleh suatu entitas. Oleh karena itu, penting bagi pemerintah daerah untuk dapat mengelola aset secara memadai.

Pengelolaan keuangan daerah setiap tahun dua kali akan dilakukan pemerikaan oleh BPK selaku auditor ekstern pemerintah. Dalam melakukan kegiatan audit laporan keuangan pemerintah daerah, BPK akan melakukan audit hingga ke tingkat SKPD, guna melihat kewajaran penyajian laporan keuangan SKPD. Permasalahan pengelolaan aset daerah hampir menjadi faktor penyebab terganjalnya pemberian opini Wajar Tanpa Pengeculian (WTP) atas hasil audit laporan keuangan oleh BPK. Demikian juga halnya dengan pemerintah daerah Provinsi DKI Jakarta, 
provinsi dengan APBD terbesar dan memiliki nilai aset tetap terbesar dibandingkan dengan daerah-daerah lainnya, dalam 2 (dua) tahun terakhir (tahun anggaran 2013 dan 2014) "hanya" mendapatkan opini Wajar Dengan Pengecualian (WDP) dengan paragraf penjelas. Perubahan opini BPK yang diperoleh Pemerintah Provinsi DKI Jakarta selama 5 tahun terakhir, salah satu catatan penting penyebabnya adalah masalah pengelolaan atau manajemen aset tetap yang selama ini dilaksanakan oleh Pemerintah DKI Jakarta, meskipun selama beberapa tahun terakhir pengelolaan aset tetap sudah mulai mengalami perbaikan. Perhatian dan upaya yang maksimal sangat diperlukan untuk membenahi pengelolaan aset tetap, mengingat besarnya jumlah nilai aset tetap yang harus dikelola. Tabel 1 memperlihatkan jumlah nilai aset tetap Pemprov DKI Jakarta dari tahun 2011 sampai dengan tahun 2015 berdasarkan Laporan Hasil Pemeriksaan Badan Pemeriksa Keungan (BPK) Perwakilan Provinsi DKI Jakarta tahun 2011 sampai tahun 2015.

Tabel 1 Jumlah aset tetap Provinsi DKI Jakarta tahun 2011-2015

\begin{tabular}{cccc}
\hline Tahun & $\begin{array}{c}\text { Aset Tetap } \\
(\mathbf{R p})\end{array}$ & $\begin{array}{c}\text { Akumulasi Penyusutan } \\
(\mathbf{R p})\end{array}$ & $\begin{array}{c}\text { Jumlah Aset Tetap } \\
(\mathbf{R p})\end{array}$ \\
\hline 2011 & 335.07 triliun & - & 335.07 triliun \\
2012 & 342.28 triliun & - & 342.28 triliun \\
2013 & 332.88 triliun & - & 332.88 triliun \\
2014 & 341.98 triliun & - & 341.98 triliun \\
2015 & 363.58 triliun & $(29.18$ triliun $)$ & 334.40 triliun
\end{tabular}

Sumber : Laporan Hasil Pemeriksaan BPK Tahun 2011-2015

Kesemua aset tetap yang dimiliki oleh pemerintah daerah Provinsi DKI Jakarta dicatat didalam Kartu Inventaris Barang (KIB) dan juga laporan-laporan BMD lainnya sesuai dengan Permendagri No. 19 Tahun 2016. Aset tetap yang dimiliki oleh pemerintah daerah diperoleh dari APBD, hibah atau sumbangan dari masyarakat, barang yang diperoleh sebagai pelaksanaan dari perjanjian/ kontrak, barang yang diperoleh berdasarkan ketentuan peraturan perundang-undangan, barang yang diperoleh berdasarkan putusan pengadilan yang telah mempunyai kekuatan hukum tetap atau barang yang diperoleh kembali dari hasil divestasi atas penyertaan modal pemerintah daerah. Perkembangan jumlah total aset tetap setiap tahun di Provinsi DKI Jakarta naik setiap tahunnya, khususnya di tahun 2015 Pemda Provinsi DKI Jakarta mulai menerapkan akuntansi basis akrual sehingga di tahun ini mulai menghitung penyusutan atas aset tetap.

Siagian (2012) menjelaskan bahawa manajemen adalah pengelolaan yang dapat diklasifikasikan ke dalam fungsi-fungsi organik manajemen yaitu perencanaan, pengorganisasian, penggerakan, pengawasan dan penilaian. Kelima fungsi manajerial lebih sering dikenal dengan fungsi manajemen POAC (planning, organizing, actuacting and controlling). Demikian halnya dalam pengelolaan aset tetap daerah, tahapantahapan yang ada mencerminkan keempat fungsi manajemen organisasi. Setiap tahapan pengelolaan saling berkaitan yang tidak mungkin dipisahkan satu sama lain. Semakin kuat koordinasi antar tiap tahapan, akan semakin baik pengelolaan aset di suatu pemerintah daerah. 


\section{METODOLOGI}

Penelitian dilakukan di SKPDSKPD di lingkungan Pemerintah Provinsi DKI Jakarta serta BPAD yang melaksanakan tugas koordinator pengelolaan aset daerah. Jenis data yang digunakan dalam penelitian ini terdiri dari data primer dan data sekunder. Data primer diperoleh dengan cara observasi langsung, wawancara dan penyebaran kuesioner. Sedangkan untuk mendapatkan data sekunder berasal dari studi pustaka dan kajian terhadap literatur terkait.

Responden terdiri dari pengurus barang/pejabat yang ditunjuk pengurus barang di 45 SKPD/UKPD/UPB dan expert responden yang memahami pengelolaan keuangan dan aset di Pemprov DKI Jakarta dan dipilih secara purposive sampling. Pemilihan responden berdasarkan pertimbangan bahwa responden merupakan pejabat yang bertugas melakukan penyusunan laporan BMD yang sesuai tugas pokok dan fungsinya seperti yang tercantum dalam Peraturan Menteri Dalam Negeri Nomor 19 Tahun 2016 tentang teknis Pengelolaan Barang Milik Daerah pasal 1 ayat 19. Data sekunder diperoleh dari Laporan Hasil Pemeriksaan Badan Pemeriksa Keuangan tahun 2011 - 2015, dokumen serta regulasi terkait dan relevan dalam penelitian ini. Alat analisis yang digunakan untuk sesuai dengan urutan tujuan dalam penelitian ini adalah: (1) Analisis Gap dan (2) deskripsi kualitatif.

Metode gap analysis akan membandingkan kondisi yang diinginkan dengan kondisi yang sedang dijalankan (Bappenas, 2009). Metode pembandingan dalam penelitian ini akan melihat bagaimana seharusnya program atau kegiatan dijalankan menurut ketentuan yang berlaku, dengan realisasi pelaksanaan program atau kegiatan yang beralngsung selama ini di pemerintah daerah Provinsi DKI Jakarta dalam pengelolaan aset tetapnya. Metode kedua yang akan digunakan untuk mencapai tujuan ini, selain masih berkesinambungan dengan hasil metode gap analysis, juga diperoleh melalui studi pustaka dan deskriptif kualitatif. Pengertian deskriptif kualitatif yaitu suatu preosedur penelitian yang menggunakan data deskriptif berupa kata-kata tertulis atau lisan dari orag-orang dan pelaku yang dapat diamati. Pendekatan kualitatif merupakan suatu prosedur penelitian yang menghasilkan data deskriptif berupa ucapan atau tulisan dan prilaku yang dapat diamati dari suatu subyek (Furchan, 1992). Untuk mengidentifikasi faktor kelemahan dan kekuatan yang berpengaruh terhadap pengelolaan dan pelaporan BMD peneliti melakukan wawancara terhadap expert responden dalam pengelolaan keuangan dan aset serta yang compatibel dalam menentukan arah kebijakan pengelolaan aset di Pemprov DKI Jakarta

\section{HASIL DAN PEMBAHASAN}

\section{Evaluasi pengelolaan aset tetap pada Pemerintah Provinsi DKI Jakarta}

Analisis ini menjelaskan persepsi responden terhadap realisasi pengelolaan aset dibandingkan dengan kondisi yang diinginkan atau sesuai dengan Permendagri Nomor 19 tahun 2016. Berdasarkan hasil pengolahan data terhadap wawancara dan kuesioner terhadap 45 respondenn diperoleh jawaban masing-masing tahapan pengelolaan BMD dengan hasil sebagaimana disajikan pada Tabel 2. 
Tabel 2 Hasil Analisis GAP

\begin{tabular}{ccccc}
\hline Tahapan & $\begin{array}{c}\text { Jumlah sub } \\
\text { komponen }\end{array}$ & Fit & $\begin{array}{c}\text { Persentase Simpulan } \\
\text { Partial }\end{array}$ & Gap \\
\hline Perencanaan & 6 & 33.33 & 33.33 & 33.33 \\
Pengorganisasian & 5 & 60 & 20 & 20 \\
Pelaksanaan & 23 & 30.43 & 47.83 & 21.74 \\
Pengendalian & 4 & 50 & 25 & 25 \\
Total rata-rata & & 43.44 & 31.54 & 25.02 \\
\hline
\end{tabular}

Dari Tabel 2, jika kondisi yang diinginkan adalah pada kondisi fit, sedangkan kondisi yang belum sesuai adalah gabungan kondisi partial dan gap, maka dapat disimpulkan dari persepsi responden bahwa tahap pelaksanaan merupakan tahap yang memiliki kesenjangan paling besar. Kesenjangan tahap pelaksanaan berbeda sedikit dengan kesenjangan pada tahap perencanaan, artinya bahwa tahap pelaksanaan dan tahap perencanaan adalah dua tahap yang berkaitan paling erat serta tahap yang saling menentukan satu sama lain. Tahap selanjutnya yang memiliki kesenjangan cukup besar adalah tahap pengendalian dan tahap pengorganisasian. Semakin besar nilai partial dan gap, maka kondisi yang sedang berjalan semakin belum sesuai dengan ketentuan. Gambaran mengenai pembandingan kondisi yang yang dilaksanakan dengan kondisi yang diinginkan untuk beberapa sub komponen dalam setiap tahap pengelolaan aset seperti tersaji di dalam Lampiran 1.

\section{Faktor-faktor Kelemahan Pengelolaan Aset di Pemprov DKI Jakarta}

Berdasarkan hasil analisis gap terhadap pengelolaan BMD, yaitu pada fungsi manajerial perencanaan, penyebab masih terjadinya kesenjangan adalah kekurangpahaman dari pihak BPAD Pemprov DKI Jakarta mengenai dokumen pendukung yang berkaitan dengan perencanaan kebutuhan aset, serta kurangnya sinkronisasi sistem perencanaan kebutuhan aset dengan sistem perencanaan anggaran secara umum.

Fungsi pengorganisasian masih belum optimal dilaksanakan karena struktur organisasi Pemprov DKI Jakarta yang berbeda dengan pemerintah daerah lainnya, banyaknya UKPD/ UPB yang ada, serta dinamika pergantian Kepala Daerah selama lima sampai sepuluh tahun terakhir. Dinamika organisasi memberikan dampak terhadap pola saluran informasi komunikasi dan kebijakan organisasi yang secara tidak langsung mempengaruhi dalam pengelolaan aset.

Kesenjangan yang terdapat pada fungsi pelaksanaan disebabkan karena pengamanan hukum dan fisik aset yang masih lemah, belum adanya sistem informasi aset yang konsisten selama sepuluh tahun terakhir, lemahnya pendokumentasian atas kepemilikan aset, proses penerbitan SK Penghapusan aset yang memakan waktu yang lama, serta keterbatasan kualitas dan kuantitas SDM yang menangani aset, baik di BPAD maupun di SKPD/UKPD/UPB.

Fungsi pengendalian masih terjadi kesenjangan disebabkan oleh kurangnya dukungan serta komitmen secara nyata dari Kepala SKPD/ UKPD/ UPB terhadap pengelolaan aset di lingkungan unit kerjanya. Dukungan dari Kepala unit kerja sangat dirasakan manfaatnya oleh para pengurus barang dalam mengelola aset yang menjadi kewenangan unit kerjanya. Dukungan pimpinan memberikan pengaruh pada motivasi pengurus barang untuk menjalankan tugas pengelolaan aset secara tertib dan 
penuh tanggung jawab. Demikian juga dukungan dan komitmen yang tinggi dari Gubernur dalam mendukung pengelolaan aset sangat dibutuhkan. Bentuk dukungan berupa pembuatan peraturan gubernur yang menjamin pengelolaan aset adalah bagian penting dari manajemen pemerintah daerah, SK Gubernur pengangkatan pengurus barang pembantu di tingkat UPB, percepatan proses penghapusan aset dengan batasan-batasan nilai tertentu dan klasifikasi tertentu, serta peraturan daerah atau peraturan gubernur lainnya yang mendukung lancarnya pengelolaan aset daerah.

\section{Optimisasi Manajemen Aset Tetap Pemprov DKI Jakarta}

Kesenjangan yang terdapat di setiap fungsi manajemen aset tetap menghambat pengelolaan pemerintahan yang baik di Pemprov DKI Jakarta. Upaya-upaya perlu dilakukan agar pengelolaan aset tetap dapat dilakukan secara lebih efektif efisien, transparan, responsif dan merata bagi kepentingan masyarakat umum, dijalankan penuh integritas dan professional serta berakuntabilitas. Pada akhirnya jika upaya tersebut dapat dijalankan maka manajemen aset tetap akan mencapai titik optimum dalam pelaksanaannya, yaitu memberikan kepuasan tertinggi bagi masyarakat sebagai stakeholder utama pemerintah daerah serta mendapatkan penilaian tertinggi dari sisi pengawasan, yang menyatakan bahwa pengelolaan pemerintah di Pemprov DKI Jakarta telah dijalankan secara good and clean governance. Langkah strategis yang ditentukan dengan memperhatikan penyebab kesenjangan pada setiap fungsi manajemen serta diharapkan dapat meminimalisir terulangnya kondisi yang menyebabkan kesenjangan sebelumnya. Upaya strategis untuk mengoptimalkan manajemen aset tetap yang perlu dilakukan oleh Pemprov DKI Jakarta seperti tersaji pada Tabel 3.

\section{Tabel 3 Upaya Strategis Optimisasi Manajemen Aset Tetap Pemprov DKI Jakarta}

\begin{tabular}{|c|c|c|c|}
\hline $\begin{array}{l}\text { Fungsi Manajemen Dan } \\
\text { Penyebab Kesenjangan }\end{array}$ & Upaya Strategis & $\begin{array}{c}\text { Rencana Jangka } \\
\text { Waktu }\end{array}$ & Aktor \\
\hline $\begin{array}{l}\text { 1. Perencanaan } \\
\text { a. Belum sinkronnya sistem } \\
\text { perencanaan kebutuhan } \\
\text { aset dengan perencanaan } \\
\text { program kegiatan pemda } \\
\text { secara umum. } \\
\text { Kurangnya pemahaman } \\
\text { BPAD sebagai SKPD } \\
\text { koordinator dalam hal } \\
\text { perencanaan kebutuhan } \\
\text { aset yang memberikan } \\
\text { dampak pada pengelolaan } \\
\text { aset. }\end{array}$ & $\begin{array}{l}\text { Membangun sistem } \\
\text { informasi aset yang } \\
\text { mengintegrasikan seluruh } \\
\text { tahapan pengelolaan aset } \\
\text { serta terintegrasi dengan } \\
\text { sistem informasi keuangan } \\
\text { akuntansi dan e-budgeting } \\
\text { 1) Penambahan personil di } \\
\text { BPAD yang memahami } \\
\text { proses perencanaan, } \\
\text { keuangan akuntansi serta } \\
\text { pengendalian internal } \\
\text { 2) Peningkatan kapabilitas } \\
\text { SDM di BPAD } \\
\text { 3) Melakukan studi } \\
\text { banding dengan sistem } \\
\text { BMN yang dikembangkan } \\
\text { oleh Kementerian } \\
\text { Keuangan. }\end{array}$ & 1 tahun & $\begin{array}{l}\text { BPAD } \\
\text { Bappeda } \\
\text { Dinas Komunikasi, } \\
\text { Informatika dan } \\
\text { Statistik }\end{array}$ \\
\hline
\end{tabular}




\begin{tabular}{|c|c|c|c|}
\hline $\begin{array}{l}\text { Fungsi Manajemen Dan } \\
\text { Penyebab Kesenjangan }\end{array}$ & Upaya Strategis & $\begin{array}{c}\text { Rencana Jangka } \\
\text { Waktu }\end{array}$ & Aktor \\
\hline $\begin{array}{l}\text { 2. Pengorganisasian } \\
\text { a. Banyaknya SKPD/UKPD/ } \\
\text { UPB }\end{array}$ & $\begin{array}{l}\text { Menginventarisir jumlah } \\
\text { UPB secara pasti dan up to } \\
\text { date serta menuangkannya } \\
\text { ke dalam Peraturan } \\
\text { Gubernur termasuk alur } \\
\text { pertanggungjawaban aset. }\end{array}$ & 6 bulan & BPAD dan SKPD \\
\hline $\begin{array}{l}\text { b. Dinamika pergantian kepala } \\
\text { daerah }\end{array}$ & $\begin{array}{l}\text { Merumuskan suatu } \\
\text { peraturan daerah mengenai } \\
\text { sistem tata kerja organisasi } \\
\text { pengelola aset yang dapat } \\
\text { mengantisipasi terjadinya } \\
\text { pergantian Gubernur }\end{array}$ & 6 bulan & $\begin{array}{l}\text { PAD, BPKD, DPRD } \\
\text { dan Pimpinan Daerah }\end{array}$ \\
\hline $\begin{array}{l}\text { 3. Pelaksanaan } \\
\text { a. Pengamanan hukum dan } \\
\text { fisik aset yang masih } \\
\text { lemah }\end{array}$ & $\begin{array}{l}\text { 1) Inventarisasi dokumen } \\
\text { kepemilikan aset } \\
\text { dengan } \\
\text { memperhatikan status } \\
\text { masing-masing aset } \\
\text { 2) } \\
\text { Membangun sistem } \\
\text { informasi dokumen } \\
\text { kepemilikan aset } \\
\text { 3) Meningkatkan } \\
\text { legalitas aset-aset } \\
\text { yang dimiliki } \\
\text { Menginventarisir aset } \\
\text { yang belum } \\
\text { diamankan secara } \\
\text { fisik seperti } \\
\text { pemasangan batas } \\
\text { kepemilikan, plang } \\
\text { kepemilikan aset, } \\
\text { labeling pada fisik } \\
\text { asset }\end{array}$ & $\begin{array}{c}1 \text { tahun simultan } \\
\text { dengan } \\
\text { inventarisasi } \\
1-2 \text { tahun } \\
1 \text { tahun }\end{array}$ & $\begin{array}{l}\text { BPAD dan Dinas } \\
\text { Komunikasi, } \\
\text { Informatika dan } \\
\text { Statistik } \\
\text { BPAD dan Biro } \\
\text { Hukum } \\
\text { BPAD dan SKPD }\end{array}$ \\
\hline 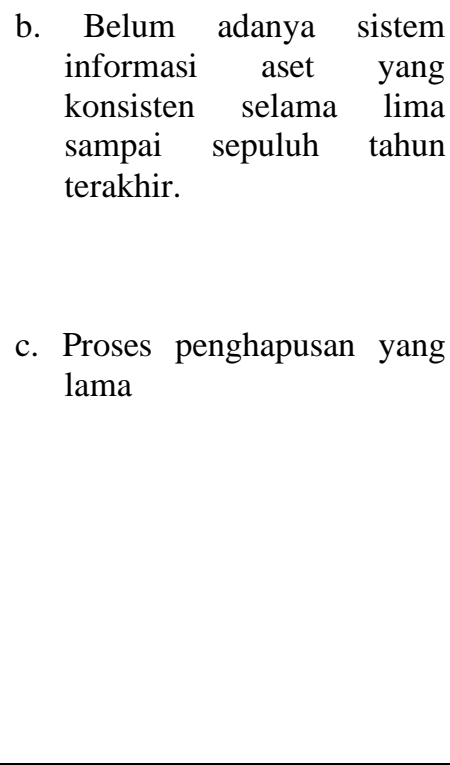 & $\begin{array}{l}\text { Membangun sistem } \\
\text { informasi aset yang } \\
\text { mengintegrasikan seluruh } \\
\text { tahapan pengelolaan aset } \\
\text { serta terintegrasi dengan } \\
\text { sistem informasi keuangan } \\
\text { akuntansi dan e-budgeting } \\
\text { 1) Membuat kebijakan } \\
\text { daerah yang mengatur } \\
\text { mengenai penghapusan } \\
\text { aset dengan batasan nilai } \\
\text { tertentu dan klasifikasi } \\
\text { tertentu tanpa bertentangan } \\
\text { dengan aturan di atasnya. } \\
\text { 1)Penambahan personil } \\
\text { pengelola aset di BPAD } \\
\text { dan SKPD/UKPD/UPB } \\
\text { 2)Peningkatan kapabilitas } \\
\text { SDM pengelola aset di }\end{array}$ & $\begin{array}{l}1-2 \text { tahun } \\
6 \text { bulan }\end{array}$ & $\begin{array}{l}\text { BPAD } \\
\text { dan Dinas } \\
\text { Komunikasi, } \\
\text { Informatika dan } \\
\text { Statistik } \\
\text { BPAD, BPKD, } \\
\text { Sekretariat Daerah }\end{array}$ \\
\hline
\end{tabular}




\begin{tabular}{|l|l|c|l|}
\hline \multicolumn{1}{|c|}{$\begin{array}{c}\text { Fungsi Manajemen Dan } \\
\text { Penyebab Kesenjangan }\end{array}$} & \multicolumn{1}{|c|}{ Upaya Strategis } & $\begin{array}{c}\text { Rencana Jangka } \\
\text { Waktu }\end{array}$ & \multicolumn{1}{|c|}{ Aktor } \\
\hline $\begin{array}{l}\text { d. Keterbatasan SDM } \\
\text { pengelola aset }\end{array}$ & $\begin{array}{l}\text { BPAD dan SKPD/UKPD/ } \\
\text { UPB }\end{array}$ & $1-3$ tahun & BKD \\
& $\begin{array}{l}\text { BPAD, } \\
\text { SKPD/UKPD/UPB } \\
\text { dan Badan } \\
\text { Pengembangan SDM }\end{array}$ \\
\hline $\begin{array}{l}\text { 4. Pengendalian } \\
\text { Belum maksimalnya } \\
\text { dukungan Kepala Unit Kerja } \\
\text { dan Pimpinan Daerah terhadap } \\
\text { pelaksanaan tugas pengelolaan } \\
\text { aset }\end{array}$ & $\begin{array}{l}\text { Membuat pakta integritas } \\
\text { serta sanksi bagi Kepala }\end{array}$ & $\begin{array}{l}\text { Unit Kerja yang lalai } \\
\text { melakukan pembinaan dan } \\
\text { pengendalian terhadap } \\
\text { pengelolaan aset unit } \\
\text { kerjanya }\end{array}$ & $\begin{array}{l}\text { Depalan } \\
\text { SKPD/UKPD/UPB } \\
\text { dan Gubernur }\end{array}$ \\
\hline
\end{tabular}

\section{SIMPULAN DAN SARAN}

\section{Simpulan}

Berdasarkan hasil dan pembahasan yang telah disajikan sebelumnya, maka dapat disimpulkan sebagai berikut:

1. Tahapan pengelolaan aset tetap merupakan cerminan dari empat fungsi manajerial pengelolaan barang milik daerah, yang di masing-masing fungsinya masih terdapat kesenjangan antara kondisi yang sedang dijalankan oleh Pemprov DKI dengan kondisi yang diinginkan yaitu sesuai dengan aturan ketentuan yang berlaku.

2. Penyebab terjadinya kesenjangan di setiap fungsi atau tahapan secara umum disebabkan oleh belum konsistennya sistem aset dan masih lemahnya pendokumentasian kepemilikan aset, dinamika pergantian Kepala Daerah selama lima sampai sepuluh tahun terakhir, serta banyaknya SKPD/UKPD/UPB.

3. Upaya strategis perlu dilakukan oleh Pemprov DKI Jakarta agar pengelolaan aset dapat dilakukan secara lebih tertib, profesional, transparan, partisipatif dan responsif serta berakuntabilitas.

\section{Saran}

Beberapa hal yang dapat disampaikan sebagai saran antara lain:

1. Menguatkan sistem informasi aset yang mampu mengintegrasikan seluruh tahapan pengelolaan aset, friendly user, konsisten, terintegrasi dengan sistem keuangan akuntasi serta dapat digunakan sebagai alat pengambilan keputusan bagi para manajemen

2. Melakukan inventarisasi dokumen kepemilikan aset, khusunya tanah dan bangunan, meningkatkan legalitas dokumen kepemilikan serta membangun dan mengembangkan sistem aset khusus untuk dokumen kepemilikan aset

3. Melakukan penguatan sumber daya manusia pengelola barang di tingkat SKPD/UKPD/UPB secara terus menerus serta meningkatkan dukungan para pimpinan daerah dari tingkat UPB hingga Gubernur kepada pelaksanaan tugas para pengelola barang. 


\section{DAFTAR PUSTAKA}

[BAPPENAS] Badan Perencanaan Pembangunan Nasional. 2009. Pedoman Evaluasi Kinerja Pembangunan Sektoral. Jakarta (ID): BAPPENAS

Departemen Agama. 2007. Konsep, Strategi dan Implementasi Good Governance Dalam Pemerintahan. Jakarta (ID): Itjen Departemen Agama

Furchan A. 1992. Pengantar Metode Penelitian Kualitatif. Surabaya (ID): Usaha Nasional
Hidayat M. 2012. Manajemen Aset (Privat dan Publik). Jogjakarta (ID): LaksBang PRESSindo

Kementerian Dalam Negeri. 2016. Peraturan Menteri Dalam Negeri No 19 Tahun 2016 tentang Pedoman Pengelolaan BMD. Jakarta (ID). Dirjen Peraturan PerUUan KemenkumHAM.

Sekretariat Negara. 2003. Undangundang Nomor 17 Tahun 2003 tentang Keuangan Negara. Jakarta (ID). Sekneg

Siagian SP. 2012. Fungsi-fungsi Manajerial Edisi Revisi. Jakarta (ID): PT Bumi Aksara 
Lampiran 1. Hasil Analisis GAP pengelolaan Aset tetap Pemerintah Provinsi DKI Jakarta

\section{Uraian tahapan dan \\ 1. Perencanaan \\ a. Perencanaan kebutuhan BMD disusun dengan memperhatikan kebutuhan pelaksanaan tugas dan fungsi SKPD serta ketersediaan BMD yang ada}

b. Perencanaan kebutuhan BMD dilaksanakan setiap tahun setelah rencana (Renja) SKPD ditetapkan.

c. Perencanaan kebutuhan BMD merupakan salah satu dasar bagi SKPD untuk pengusulan anggaran

d.Perencanaan kebutuhan BMD mengacu pada Renja SKPD.

e. Pengguna Barang dan/atau Kuasa Pengguna Barang mengusulkan rencana kebutuhan pengadaan BMD dengan berpedoman pada standar harga, standar barang dan standar kebutuhan.

f. Rencana kebutuhan barang dituangkan ke dalam dokumen RKBMD mulai dari Kuasa Pengguna Barang yang dihimpun oleh Pengguna Barang dan ditetapkan oleh Pengelola Barang sebagai dasar penyusunan RKA SKPD sesuai jadwal yang telah dtentukan.

Kondisi yang sedang dijalankan
SKPD dan UKPD menyusun
perencanaan kebutuhan barang
berdasarkan kebutuhan unit kerja
masing-masing, akan tetapi di
dalam proses pembahasan
perencanaan seringkali terdapat
perubahan usulan dengan realisasi,
dan perubahan ini yang seringkali
kurang terinformasikan sampai
kepada yang mengusulkan.

Perencanaan kebutuhan pengadaan, pemeliharaan BMD dilaksanakan setiap tahun setelah Renja SKPD ditetapkan

Salah satu dasar bagi SKPD untuk mengusulkan anggaran adalah perencanaan kebutuhan barang, selain ketersediaan plafon anggaran dan kesesuaian program kegiatan dengan unit kerja di atasnya.

Perencanaan kebutuhan barang mengacu pada Renja SKPD untuk menyesuaikan ketersediaan anggaran dan keseuaian program kegiatan di tingkat Provinsi

Pengguna Barang dan/ atau Kuasa Pengguna Barang telah mengusulkan rencana kebutuhan barang dengan mengacu pada standar harga, standar barang dan standar kebutuhan.

Pengguna Barang dan/ atau Kuasa Pengguna Barang belum menuangkan rencana kebutuhan barang unit kerjanya ke dalam dokumen RKBMD sesuai Permendagri 19 tahun 2016

\section{Degree of fit}

Partial

Fit

Fit

Fit

Fit

Gap 


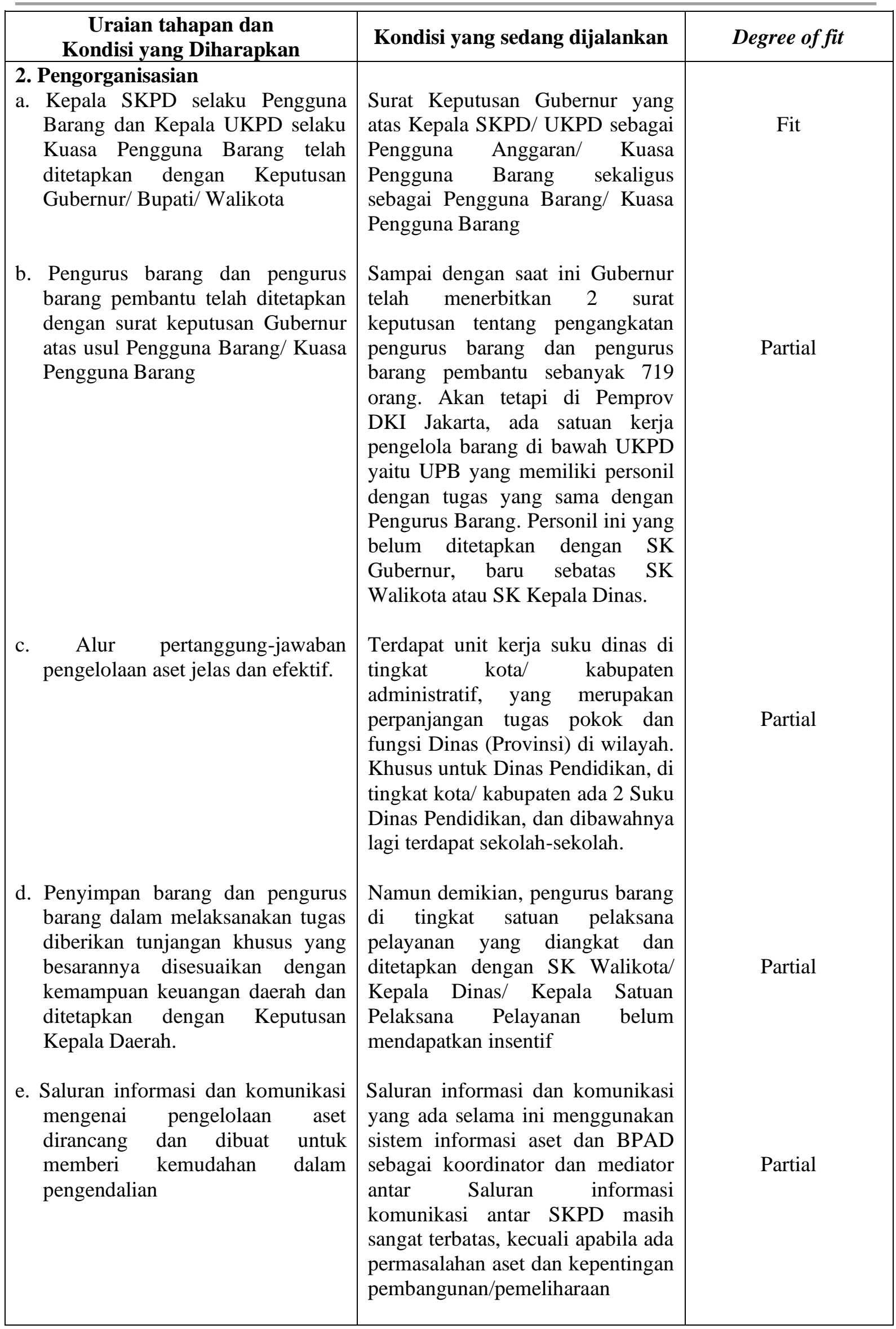




\begin{tabular}{|c|c|c|}
\hline $\begin{array}{c}\text { Uraian tahapan dan } \\
\text { Kondisi yang Diharapkan }\end{array}$ & Kondisi yang sedang dijalankan & Degree of fit \\
\hline $\begin{array}{l}\text { 3. Pelaksanaan } \\
\text { a. Pengadaan BMD dilaksanakan } \\
\text { berdasarkan prinsip efisien, } \\
\text { efektif, transparan dan terbuka, } \\
\text { bersaing, adil dan akuntabel serta } \\
\text { sesuai dengan ketentuan peraturan } \\
\text { perundang-undangan. }\end{array}$ & $\begin{array}{l}\text { Pengadaan barang di Provinsi DKI } \\
\text { Jakarta saat ini tidak lepas } \\
\text { kaitannya dengan proses } \\
\text { perencanaan penganggaran dengan } \\
\text { menggunakan sistem e-budgeting } \\
\text { serta terdapat juga sistem e- } \\
\text { catalog. Untuk proses pengadaan } \\
\text { barang/ jasa yang menggunakan } \\
\text { mekanisme pelelangan/ tender } \\
\text { barang dengan nilai di atas } 100 \\
\text { milyar dilakukan secara terpusat } \\
\text { oleh Badan Pengadaan Barang/ } \\
\text { Jasa Provinsi DKI Jakarta, } \\
\text { sedangkan nilai di bawahnya oleh } \\
\text { Tim Pengadaan SKPD }\end{array}$ & Fit \\
\hline $\begin{array}{l}\text { b. Pengguna barang wajib } \\
\text { menyampaikan laporan hasil } \\
\text { pengadaan BMD kepada Gubernur } \\
\text { melalui Pengelola Barang untuk } \\
\text { ditetapkan status penggunaannya. }\end{array}$ & $\begin{array}{l}\text { Pengguna barang/ Kuasa pengguna } \\
\text { barang telah membuat laporan } \\
\text { pengadaan sebagai bagian dari } \\
\text { penatausahaan aset serta untuk } \\
\text { kepentingan penyusunan Laporan } \\
\text { Keuangan SKPD dan Laporan } \\
\text { Keuangan Pemerintah Daerah. }\end{array}$ & Partial \\
\hline $\begin{array}{l}\text { c. Pengguna barang mengajukan } \\
\text { permohonan penetapan status } \\
\text { penggunaan barang milik daerah } \\
\text { yang diperoleh dari beban APBD } \\
\text { dan perolehan lainnya yang sah } \\
\text { kepada Gubernur. }\end{array}$ & $\begin{array}{l}\text { Pengguna barang belum membuat } \\
\text { permohonan penetapan status } \\
\text { penggunaan barang milik daerah, } \\
\text { khususnya selain tanah dan } \\
\text { bangunan, kepada Gubernur karena } \\
\text { selama ini selama aset yang telah } \\
\text { dicatat ke dalam pembukuan } \\
\text { SKPD/ UKPD secara otomatis } \\
\text { dianggap telah sah untuk } \\
\text { digunakan oleh unit kerja yang } \\
\text { bersangkutan. }\end{array}$ & Partial \\
\hline $\begin{array}{l}\text { d. Laporan hasil pengadaan yang } \\
\text { dibuat terdiri dari laporan bulanan, } \\
\text { semesteran dan tahunan. }\end{array}$ & $\begin{array}{l}\text { Pengguna Barang/ Kuasa } \\
\text { Pengguna Barang telah membuat } \\
\text { laporan hasil pengadaan barang di } \\
\text { unit kerjanya secara bulanan, } \\
\text { semesteran dan tahunan. }\end{array}$ & Fit \\
\hline $\begin{array}{l}\text { e. Pengelola barang/ pengguna barang } \\
\text { dengan persetujuan Gubernur, } \\
\text { telah membuat penetapan dan } \\
\text { perjanjian untuk pemanfaatan } \\
\text { barang milik daerah }\end{array}$ & $\begin{array}{l}\text { Provinsi DKI Jakarta telah } \\
\text { membuat perjanjian-perjanjian } \\
\text { kerjasama untuk jenis-jenis } \\
\text { pemanfaatan barang milik daerah, } \\
\text { meskipun masih banyak potensi } \\
\text { aset milik Pemprov yang belum } \\
\text { dibuatkan perjanjian kerjasamanya. }\end{array}$ & Partial \\
\hline
\end{tabular}




\begin{tabular}{|c|c|c|}
\hline $\begin{array}{c}\text { Uraian tahapan dan } \\
\text { Kondisi yang Diharapkan }\end{array}$ & Kondisi yang sedang dijalankan & Degree of fit \\
\hline $\begin{array}{l}\text { f. Pengelola barang, Pengguna barang } \\
\text { dan/ atau Kuasa Pengguna barang } \\
\text { telah melakukan pengamanan baik } \\
\text { pengamanan fisik, administrasi } \\
\text { dan pengamanan hukum, terhadap } \\
\text { aset/ barang milik daerah yang } \\
\text { menjadi penguasaannya. }\end{array}$ & $\begin{array}{l}\text { Pengamanan aset berupa } \\
\text { pengamanan administrasi yang } \\
\text { menjadi kewenangan Pengguna } \\
\text { barang/ Kuasa Pengguna barang } \\
\text { telah dilakukan atas aset yang } \\
\text { menjadi penguasaannya, akan } \\
\text { tetapi untuk pengamanan fisik dan } \\
\text { hukum sebagian besar menjadi } \\
\text { kewenangan BPAD selaku unit } \\
\text { kerja koordinasi tingkat Provinsi } \\
\text { yang menangani aset. Pengamanan } \\
\text { administrasi dilakukan dengan } \\
\text { melakukan pencatatan/ pembukuan } \\
\text { dan pelaporan atas aset yang } \\
\text { dikuasai/ dikelola oleh Pengguna } \\
\text { barang dan/ atau Kuasa Pengguna } \\
\text { barang. Pengamanan fisik atas aset } \\
\text { khususnya tanah dan bangunan } \\
\text { berupa pemagaran, pemasangan } \\
\text { tanda kepemilikan tanah dan } \\
\text { penjagaan atas semua tanah dan } \\
\text { bangunan yang dikuasai Pemprov } \\
\text { DKI Jakarta masih terus dilakukan } \\
\text { sampai dengan saat ini. } \\
\text { Pengamanan hukum berupa } \\
\text { pensertifikatan atas semua tanah } \\
\text { dan bangunan yang dikuasai oleh } \\
\text { Pemprov DKI Jakarta adalah } \\
\text { merupakan kewenangan BPAD } \\
\text { bekerjasama dengan Biro Hukum } \\
\text { Provinsi DKI Jakarta. Demikian } \\
\text { juga dengan penyimpanan atas } \\
\text { surat kepemilikan tanah, bangunan } \\
\text { dan kendaraan bermotor } \\
\text { dilaksanakan oleh BPAD. Belum } \\
\text { semua Pengguna brang/ Kuasa } \\
\text { Pengguna barang memiliki Salinan } \\
\text { atas surat kepemilikan tanah, } \\
\text { bangunan maupun kendaraan } \\
\text { bermotor. }\end{array}$ & Partial \\
\hline $\begin{array}{l}\text { g. Kuasa pengguna barang wajib } \\
\text { membuat Daftar Hasil } \\
\text { Pemeliharaan Barang yang berada } \\
\text { dalam kewenangannya dan } \\
\text { selanjutnya Pengguna barang akan } \\
\text { melakukan penelitian dan } \\
\text { membuat Laporan Hasil Penelitian } \\
\text { Pemeliharaan Barang. }\end{array}$ & $\begin{array}{l}\text { Saat ini apabila terdapat kegiatan } \\
\text { pemeliharaan atas aset tetap yang } \\
\text { merupakan kewenangan Kuasa } \\
\text { Pengguna barang, maka pencatatan } \\
\text { yang dilakukan baru sebatas pada } \\
\text { buku besar atau buku register } \\
\text { Pengurus barang pembantu, belum } \\
\text { dilakukan dengan format yang } \\
\text { seragam untuk seluruh unit kerja. } \\
\text { Demikian juga Pengguna barang }\end{array}$ & Partial \\
\hline
\end{tabular}




\begin{tabular}{|c|c|c|}
\hline $\begin{array}{c}\text { Uraian tahapan dan } \\
\text { Kondisi yang Diharapkan }\end{array}$ & Kondisi yang sedang dijalankan & Degree of fit \\
\hline & $\begin{array}{l}\text { belum membuat Laporan Hasil } \\
\text { penelitian Pemeliharaan Barang. }\end{array}$ & \\
\hline $\begin{array}{l}\text { h. Dalam rangka tertib pemeliharaan, } \\
\text { pengurus barang dan pengurus } \\
\text { barang pembantu membuat kartu } \\
\text { pemeliharaan/ perawatan atas aset. }\end{array}$ & $\begin{array}{l}\text { Pengurus barang dan pengurus } \\
\text { barang pembantu sampai dengan } \\
\text { saat ini baru membuat kartu } \\
\text { pemeliharaan/ perawatan atas aset } \\
\text { berupa kendaraan bermotor. Untuk } \\
\text { aset lainnya, pencatatan } \\
\text { pemeliharaan dilakukan pada buku } \\
\text { register barang }\end{array}$ & Partial \\
\hline $\begin{array}{l}\text { i. Penetapan nilai aset tetap/ barang } \\
\text { milik daerah telah dilakukan } \\
\text { dengan perpedoman pada Standar } \\
\text { Akuntansi Pemerintah (SAP) }\end{array}$ & $\begin{array}{l}\text { Penilaian atas aset Pemprov DKI } \\
\text { Jakarta telah mengacu pada SAP } \\
\text { dan kebijakan akuntansi Provinsi, } \\
\text { khususnya yang mengatur masalah } \\
\text { kapitalisasi aset. }\end{array}$ & Fit \\
\hline $\begin{array}{l}\text { j. Pemindahtanganan aset telah } \\
\text { dilakukan sesuai dengan ketentuan } \\
\text { dengan dilengkapi oleh dokumen } \\
\text { pendukung yang memadai. }\end{array}$ & $\begin{array}{l}\text { Pemindahtanganan yang banyak } \\
\text { terjadi di Provinsi DKI Jakarta } \\
\text { adalah berupa penjualan, hibah dan } \\
\text { penyertaam modal pemerintah } \\
\text { daerah. Untuk aset yang } \\
\text { dipindahtangankan melalui } \\
\text { mekanisme penjualan dan } \\
\text { penyertaan modal pemerintah } \\
\text { daerah telah didukung dengan } \\
\text { dokumen yang cukup memadai, } \\
\text { namun pemindahtangan yang } \\
\text { berupa hibah belum seluruhnya } \\
\text { didukung dengan dokumen Berita } \\
\text { Acara Serah Terima Hibah Aset. }\end{array}$ & Partial \\
\hline $\begin{array}{l}\text { k. Pengguna barang membuat } \\
\text { permohonan pemusnahan aset atau } \\
\text { barang milik daerah kepada } \\
\text { Gubernur dan atas persetujuan } \\
\text { Gubernur, Pengguna barang } \\
\text { melaksanakan pemusnahan barang } \\
\text { milik daerah. }\end{array}$ & $\begin{array}{l}\text { Pengguna barang telah membuat } \\
\text { permohonan pemusnahan barang } \\
\text { kepada Gubernur melalui } \\
\text { Pengelola Barang (Sekretaris } \\
\text { Daerah), akan tetapi kewenangan } \\
\text { untuk pelaksanaan pemusnahan } \\
\text { barang ada di BPAD. }\end{array}$ & Partial \\
\hline $\begin{array}{l}\text { 1. Gubernur menerbitkan surat } \\
\text { persetujuan pemusnahan barang } \\
\text { milik daerah atas permohonan } \\
\text { pemusnahan yang disetujui. }\end{array}$ & $\begin{array}{l}\text { Gubernur menerbitkan surat } \\
\text { persetujuan pemusnahan atas } \\
\text { permohonan pemusnahan barang } \\
\text { yang disetujui, akan tetapi jangka } \\
\text { waktu penerbitan surat persetujuan } \\
\text { dengan permohonan selama ini } \\
\text { masih banyak yang belum } \\
\text { memiliki batas waktu tertentu. } \\
\text { Kondisi ini menyebabkan banyak } \\
\text { aset yang dikuasai oleh SKPD }\end{array}$ & Partial \\
\hline
\end{tabular}




\begin{tabular}{|c|c|c|}
\hline $\begin{array}{c}\text { Uraian tahapan dan } \\
\text { Kondisi yang Diharapkan }\end{array}$ & Kondisi yang sedang dijalankan & Degree of fit \\
\hline 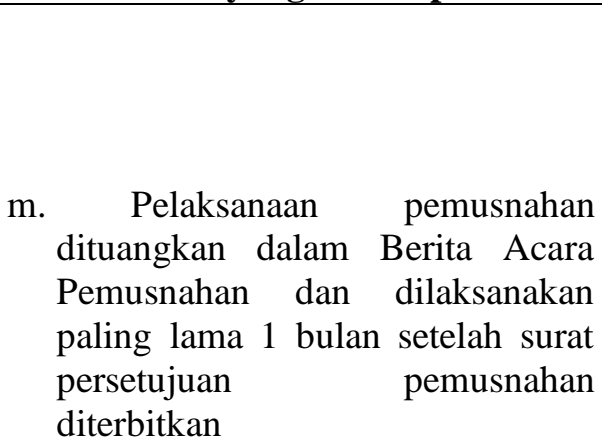 & $\begin{array}{l}\text { namun dalam kondisi rusak berat } \\
\text { yang masih terdapat di dalam } \\
\text { pencatatan aset SKPD. } \\
\text { Pelaksanaan pemusnahan telah } \\
\text { dituangkan dalam Berita Acara } \\
\text { Pemusnahan yang ditandatangani } \\
\text { oleh pihak BPAD dan SKPD } \\
\text { pemohon. }\end{array}$ & Fit \\
\hline $\begin{array}{l}\text { n. Pengguna Barang dan/ atau Kuasa } \\
\text { Pengguna barang membuat } \\
\text { permohonan penghapusan aset } \\
\text { kepada Gubernur melalui } \\
\text { Pengelola barang dan atas dasar } \\
\text { surat permohonan yang teah } \\
\text { diteliti validitas nya, maka } \\
\text { Gubernur melalui Pengelola } \\
\text { barang akan menerbitka surat } \\
\text { persetujuan penghapusan aset atau } \\
\text { barang milik daerah }\end{array}$ & $\begin{array}{l}\text { Pengguna barang dan/atau } \\
\text { Kuasa pengguna barang selama ini } \\
\text { secara periodik telah membuat } \\
\text { surat usulan penghapusan atas aset } \\
\text { yang tidak dapat lagi digunakan } \\
\text { oleh SKPD/ UKPD maupun aset } \\
\text { yang tidak lagi dalam kewenangan } \\
\text { SKPD/ UKPD yang bersangkutan, } \\
\text { akan tetapi proses penelitian } \\
\text { permohonan sampai dengan } \\
\text { penerbitan persetujuan } \\
\text { penghapusan masih memakan } \\
\text { waktu yang lama. }\end{array}$ & Partial \\
\hline $\begin{array}{l}\text { o. Pengguna barang atau Kuasa } \\
\text { Pengguna barang membuat } \\
\text { laporan penghapusan barang milik } \\
\text { daerah dan membuat Perubahan } \\
\text { Daftar Barang Pengguna/ Kuasa } \\
\text { Pengguna serta dilaporkan dalam } \\
\text { Laporan Semesteran dan Laporan } \\
\text { Tahunan }\end{array}$ & $\begin{array}{l}\text { Pengguna barang melalui Pengurus } \\
\text { barang maupun pengurus barang } \\
\text { pembantu selama ini telah } \\
\text { membuat laporan penghapusan } \\
\text { barang namun tidak membuat } \\
\text { Perubahan Daftar Barang } \\
\text { Pengguna/ Kuasa Pengguna sesuai } \\
\text { format yang ada di dalam } \\
\text { Permendagri Nomor } 19 \text { tahun } \\
\text { 2016. Pencatatan atas perubahan } \\
\text { daftar barang karena penghapusan } \\
\text { hanya dilakukan dengan cara } \\
\text { mengeluarkan kode barang yang } \\
\text { telah dihapuskan dari KIB yang } \\
\text { telah ada. Pada saat penyusunan } \\
\text { Laporan Keuangan Semesteran } \\
\text { maupun Laporan Tahunan SKPD, } \\
\text { aset atau barang milik daerah yang } \\
\text { telah dihapuskan akan } \\
\text { dicantumkan sebagai mutasi } \\
\text { kurang aset tahun berjalan. }\end{array}$ & Partial \\
\hline $\begin{array}{l}\text { p. Pengguna barang dan Kuasa } \\
\text { Pengguna barang melalui pengurus } \\
\text { barang dan pengurus barang } \\
\text { pembantu melakukan pencatatan }\end{array}$ & $\begin{array}{l}\text { Pengurus barang dan pengurus } \\
\text { barang pembantu telah membuat } \\
\text { pencatatan aset atau barang milik } \\
\text { daerah yang menjadi kewenangan }\end{array}$ & Fit \\
\hline
\end{tabular}




\begin{tabular}{|c|c|c|}
\hline $\begin{array}{c}\text { Uraian tahapan dan } \\
\text { Kondisi yang Diharapkan }\end{array}$ & Kondisi yang sedang dijalankan & Degree of fit \\
\hline $\begin{array}{l}\text { atau pembukuan aset atau barang } \\
\text { milik daerah menurut } \\
\text { penggolongan dan kodefikasi aset } \\
\text { serta membuat Laporan Barang } \\
\text { Milik Daerah semesteran dan } \\
\text { tahunan. }\end{array}$ & $\begin{array}{l}\text { SKPD/ UKPD-nya ke dalam KIB, } \\
\text { KIR dan Buku Inventaris. } \\
\text { Pencatatan aset di Provinsi DKI } \\
\text { Jakarta menggunakan sistem } \\
\text { informasi aset. }\end{array}$ & \\
\hline $\begin{array}{l}\text { q. Pemerintah daerah melakukan } \\
\text { inventarisasi barang milik daerah } \\
\text { paling sedikit } 1 \text { kali dalam } 5 \text { tahun. }\end{array}$ & $\begin{array}{l}\text { Mengacu salah satunya dari hasil } \\
\text { sensus BMD 2013, menjadi lebih } \\
\text { akurat. Pada kegiatan inventarisasi } \\
\text { ini sekaligus juga dilakukan } \\
\text { kegiatan labelisasi ratau } \\
\text { penempelan/pemasangan identitas } \\
\text { barang hasil inventarisasi pada } \\
\text { fisik barang. } \\
\text { Sensus barang telah dilakukan } \\
\text { pada tahun } 2008 \text { dan } 2013 \text {. }\end{array}$ & Fit \\
\hline $\begin{array}{l}\text { r. Kuasa Pengguna barang menyusun } \\
\text { laporan barang semesteran dan } \\
\text { tahunan untuk disampaikan kepada } \\
\text { Pengguna barang, dan Pengguna } \\
\text { barang akan menghimpun laporan } \\
\text { tersebut sebagai bahan penyusunan } \\
\text { laporan keuangan (Neraca) } \\
\text { semesteran dan tahunan. }\end{array}$ & $\begin{array}{l}\text { Penyusunan laporan barang } \\
\text { semesteran dan tahunan telah } \\
\text { dibuat oleh PB/KPB bersamaan } \\
\text { dengan proses penginputan mutasi } \\
\text { aset pada KIB dengan } \\
\text { menggunakan SIA. Dokumen } \\
\text { pencatatan dan pelaporan aset } \\
\text { menjadi bahan penyusunan Neraca } \\
\text { SKPD/ UKPD, sekaligus sebagai } \\
\text { bahan penyusunan Laporan } \\
\text { Keuangan Pemerintah Daerah } \\
\text { Semesteran dan Tahunan. }\end{array}$ & Fit \\
\hline $\begin{array}{l}\text { s. Pemerintah daerah mengadakan } \\
\text { suatu sistem dan aplikasi yang } \\
\text { memadai, konsisten serta } \\
\text { memudahkan bagi pengguna (user } \\
\text { friendly) dalam melakukan } \\
\text { penatausahaan aset dan pelaporan } \\
\text { yang sesuai dengan peraturan } \\
\text { ketentuan terbaru, yang sekaligus } \\
\text { berfungsi sebagai alat } \\
\text { pengendalian dalam pengelolaan } \\
\text { aset. }\end{array}$ & $\begin{array}{l}\text { SIA dikembangkan oleh Dinas } \\
\text { Informatika, Komunikasi dan } \\
\text { Statistik Provinsi DKI Jakarta } \\
\text { bekerjasama dengan BPAD. Sistem } \\
\text { e-asset baru digunakan di tahun } \\
\text { anggaran } 2016 \text { setelah sebelumnya } \\
\text { menggunakan sistem excell dan } \\
\text { SIMDA BMD yang dikembangkan } \\
\text { oleh BPKP. }\end{array}$ & Partial \\
\hline $\begin{array}{l}\text { 4. Pengendalian } \\
\text { a. Pengguna barang/ Kuasa Pengguna } \\
\text { barang melakukan pengawasan } \\
\text { dan pengendalian aset atau barang } \\
\text { milik daerah yang menjadi } \\
\text { kewenangannya, salah satunya }\end{array}$ & $\begin{array}{l}\text { Belum semua Pengguna barang } \\
\text { (Kepala SKPD) atau Kuasa } \\
\text { Pengguna barang (Kepala UKPD) } \\
\text { atau Kepala Satuan Pelaksana } \\
\text { Pelayanan telah melakukan }\end{array}$ & Partial \\
\hline
\end{tabular}




\begin{tabular}{|c|c|c|}
\hline $\begin{array}{c}\text { Uraian tahapan dan } \\
\text { Kondisi yang Diharapkan }\end{array}$ & Kondisi yang sedang dijalankan & Degree of fit \\
\hline $\begin{array}{lrr}\text { melalui } & \text { pemantauan } & \text { terhadap } \\
\text { pelaksanaan } & \text { tugas } & \text { pengurus } \\
\text { barang/ } & \text { pengurus } & \text { barang } \\
\text { pembantu. } & & \end{array}$ & $\begin{array}{l}\text { pengawasan dan pengendalian } \\
\text { secara intensif terhadap } \\
\text { pengelolaan aset unit kerjanya. }\end{array}$ & \\
\hline $\begin{array}{l}\text { b. Aparat pengawasan internal } \\
\text { pemerintah (APIP) dan BPK } \\
\text { melakukan audit dan/ atau } \\
\text { pengawasan terhadap pengelolaan } \\
\text { aset atau barang milik daerah }\end{array}$ & $\begin{array}{l}\text { Inspektorat Provinsi DKI Jakarta, } \\
\text { BPKP dan BPK telah melakukan } \\
\text { pengawasan terhadap pengelolaan } \\
\text { barang milik daerah. Pengawasan } \\
\text { yang dilakukan oleh Inspektorat } \\
\text { dan BPKP lebih berifat } \\
\text { pencegahan (preventif), sedangkan } \\
\text { pengawasan yang dilakukan oleh } \\
\text { BPK bersifat audit represif } \\
\text { (penindakan) karena BPK } \\
\text { merupakan auditor eksternal } \\
\text { pemerintah. }\end{array}$ & Fit \\
\hline $\begin{array}{l}\text { c. BPAD Provinsi DKI Jakarta } \\
\text { melaksanakan tugas pengelolaan } \\
\text { aset daerah, termasuk fungsi } \\
\text { pembinaan, sosialisasi dan } \\
\text { pengendalian }\end{array}$ & $\begin{array}{l}\text { BPAD telah melaksanakan fungsi } \\
\text { koordinator pengelolaan aset } \\
\text { daerah, di antaranya melakukan } \\
\text { pembinaan sosialisasi mengenai } \\
\text { peraturan ketentuan tentang barang } \\
\text { milik daerah dan hal lainnya yang } \\
\text { terkait pengelolaan aset, akan } \\
\text { tetapi belum optimal dalam } \\
\text { pelaksanaannya. }\end{array}$ & Partial \\
\hline $\begin{array}{l}\text { d. Pemerintah daerah menyusun } \\
\text { peraturan daerah atau peraturan } \\
\text { kepala daerah sebagai petunjuk } \\
\text { pelaksanaan sistem dan prosedur } \\
\text { pengelolaan aset atau barang milik } \\
\text { daerah yang sesuai dengan kondisi } \\
\text { daerahnya masing-masing, dengan } \\
\text { mengacu kepada peraturan di } \\
\text { atasnya. }\end{array}$ & $\begin{array}{l}\text { Saat ini pemerintah Provinsi DKI } \\
\text { Jakarta belum mempunyai Perda/ } \\
\text { Pergub yang mengatur tentang } \\
\text { sistem dan prosedur pengelolaan } \\
\text { BMD }\end{array}$ & Gap \\
\hline
\end{tabular}

